\title{
The Implementation Of Provisions In Article 16, Paragraph (1) Line M Of The Act No. 2 Of 2014 On The Notary's Position In Pekalongan
}

\begin{abstract}
Ade Alfriyan Rumrijono ${ }^{1}$, Adimas Dirgantara ${ }^{2}$ and Gunarto ${ }^{3}$
Abstract. This study examines the implementation of the provisions of Article 16 paragraph (1) line M UUJN in Pekalongan. This type of research is juridical empiric. These results indicate that the notary in Pekalongan has not implemented the provisions of Article 16 paragraph (1) line M UUJN. The legal consequences and responsibility for this violation is Notary agreement in question only has the strength of evidence as the Notary agreement under the hand and can be held accountability in civil and criminal law. Constraints implementation of these provisions are too large number of jobs of Public Notary, too small a value leads to low credit limit so that the Notary fees, and less understanding of the parties and the Notary of the provision itself.

Keywords: Implementation; Provisions; Notary's Position.
\end{abstract}

\section{Introduction}

Notary is a public official who is authorized to make an authentic agreement and have more authority as referred to in this Act or other. ${ }^{4}$ The task of the notary is legal relations between the parties in writing and a certain format, so it is an authentic agreement. In accordance with its authority, the Notary is a public official authorized to make an authentic agreement and other authorities. ${ }^{5}$

Other powers stipulated in the legislation among other things, the authority to certify the transactions carried out electronically (Cyber Notary), made the pledge agreement of endowment, and aircraft mortgages. ${ }^{6}$ Besides, so much authority, a notary also have an obligation to be fulfilled as a public official that is as stated in Article 16 paragraph (1) UUJN. In carrying out his duties and a Notary must cling to the Notary Code because without it, the dignity of professionalism will be lost. ${ }^{7}$

One of the problems regarding the implementation of the obligations of Notaries in the activities office and a major focus of this research is on reading and signatories to the Agreement by a Notary which regulated in Act No.2 of 2014 concerning Notary to the provisions of Article 16 paragraph (1) line $M$ reads "in running the office, a notary shall read out the agreement in front client attended by shaky at least two (2) witnesses, or four (4) witnesses specifically for the manufacture of the Agreement of Probate under arms, and signed on the spot by client, witness and Notary ".

That every agreement of Notary, before being signed, should be read prior to the client and witnesses. The reading of the agreement is part of the manufacture (verlijden) a

\footnotetext{
${ }^{1}$ Student of Master Program (S2) of Notaries Faculty of Law Universitas Islam Sultan Agung email : adealfriyan96@gmail.com

2 Students of Master of Law, Faculty of Law, Universitas Islam Sultan Agung email dimdim.aza@gmail.com

${ }^{3}$ Profesor of Faculty of Law UNISSULA

4 Law No. 2 of 2014 on the Amendment of the Act No.30 of 2004 concerning Notary Ps 1.

${ }^{5}$ Tan Thong Kie 2000 Serba-serbi Praktek Notaris Book I PT Ichtiar New Van Hoeve Jakarta p.159.

${ }^{6}$ Habib Adjie 2015 Penafsiran Tematik Hukum Notaris Indonesia Berdasarkan undang Undang Nomor 2 Tahun 2014 Tentang Perubahan Atas Undang Undang Nomor 30 Tahun 2004 Tentang Jabatan Notaris Refika Aditama Bandung p.2.

${ }^{7}$ Suhrawardi K. Lubis 2006 Etika Profesi Hukum Sinar Grafika Jakarta p. 50.
} 
agreement. And because the agreement was created by (the authorities) Notary, then read it must Notary, the Notary who read it had to be concerned. ${ }^{8}$

In the provision of Article 16 paragraph (1) line M UUJN there are three important points to be assessed within the first about reading before client Notary agreement. In the implementation, often with limited time Public Notary delegate to represent the employee in the reading of the agreement in the presence of client. more than that violations occurred not only come from the Notary but also the client, for notaries who have a partnership with a bank when the loan portfolio should have led the banks that have received the power of attorney to represent for and on behalf of the bank goes to be present in the reading of the agreement but in fact present when loan disbursements are actually legal staff who is not authorized and is not a client than the agreement.

The second point that is about the presence of two (2) witnesses included in the final agreement. In fact some of the Notary list of witnesses in the end aktanya with blank raw to be continuous so that the witnesses present did not correspond with those contained in the final agreement, except that sometimes there is only 1 (one) witnesses are present although the conditions have been obliged attended 2 (two) witnesses.

The third point that is about the signing at that time by client, witnesses, a notary. A fact that is often found just the parties who signed the act at that time, a notary and witnesses often do not sign directly on the spot.

Problems of this kind need to be examined more deeply on the implementation of the provisions of Article 16 paragraph (1) line $M$ in practice of Notary in Pekalongan, factors causing these violations and how the solution in order to minimize the offense, until the legal consequences arising and responsibilities Notary responsibility towards its employees and the problems of legal products it makes.

\section{Research Methods}

This study uses juridical empiric approach, with a primary law, especially regarding legislation concerning Notary. In this study, the data collected through the study of documents and literature study. Research on secondary legal materials derived from literature sources such as books, articles, and interviews as a supplement. These data will be analyzed by descriptive analytic.

\section{Results And Discussion}

Today the number of violations by the Public Notary mainly related to the implementation of obligations has increased so need more intensive supervision of the Supervisory Council. Oversight of Notaries done by the minister to form a Supervisory Council, amounting to 9 (nine), consisting of members of the government as much as (3) any person, organization Notary three (3) persons, and experts or academics as much (3) people. ${ }^{9}$

Notary in carrying out his obligations specifically stipulated in Article 16 (1) UUJN. Among the many such liability in this chapter I focus the discussion on the obligations of the Notary on the line $\mathrm{M}$ in Pekalongan. The provision reads Notaries in running post shall read the agreement before client in the presence of at least two (2) witnesses, or 4 (four) special witness to a agreement testament under the hand, and also signed on the spot by client, witnesses and Notary.

Based on interviews with the Maya as supervisor of the unit Bank in Pekalongan, he testified that during Notary partners in Pekalongan in carrying out the work yet to

\footnotetext{
${ }^{8}$ Daeng Naja 2012 Teknik Pembuatan Akta (Buku Wajib Kenotariatan) First Edition Buku Seru Jakarta p.113.

${ }^{9}$ Law No. 2 of 2014 on the Amendment of the Act No.30 of 2004 concerning Notary Ps 67 Verse 3
} 
implement article 16 paragraph (1) line M UUJN. In running the Notary office often represents its employees to attend once read the agreement before the parties even within a certain time just give blank certificates were then given to the bank's staff represented in the signing of the agreement of the parties. ${ }^{10}$

In this case the employee Notaries in addition to representing the Notary to appear before the parties also represent witnesses who stated in the agreement, because the witness who stated in the agreement mostly already in blank the same format so that when representing the Notary to appear before the parties are not contained in the blank format certificate, the employee was also once represented a witness which has existed in the blank formats available. ${ }^{11}$

Notary never attended a micro bank credit agreement as well as the nominal relatively small, orders / job so much that most of the notary is not able to attend all of the work. It became one of the factors that make the Notary then represent employees in doing realization / loan agreement micro banks. ${ }^{12}$

Another case with Lia as the staff at the branch office of the bank, he said that notaries who associates with a branch office is expected to present yourself and read directly to the parties. Since most of the nominal credit in the branch office is large enough so that the risks are also great considering the implementation of Article 16 Paragraph (1) line $M$ is very detrimental to the company if it is not applied in practice. ${ }^{13}$

But in some jobs that are not too risky Notary sometimes depute the staff / employees to attend the signing of the agreement in front of the party. Too much / overload of work is also being one factor failure in the implementation of Article 16 paragraph (1) line M. ${ }^{14}$

Based on the explanation above mentioned banks authors conclude that the notary in Pekalongan implement the provisions of Article 16 paragraph (1) line $M$ only at bank offices that have a risk of default is greater than minimal risk of bank defaults.

Knowledge and understanding of the provisions of this Article is necessary for the parties and the Notary. Because proficiency is a prerequisite for the validity of a treaty, these skills are authorized parties to a agreement. If only employees who read aktanya then in terms of the agreement became invalid because incompetent employees / not authorized to represent to attend the signing of the agreement in front of the party.

Based on interviews with Eny Wijayanti as a Public Notary - PPAT in Pekalongan on the implementation of the provisions of Article 16 paragraph (1) line M UUJN, he mentioned that the rules are determined to provide guidance to the Notary to keep it running straight and not turning, all rules are created inevitably accompanied sanctions binding. Failing to meet the obligation Notary pursuant to Article 16 paragraph (1) line $M$ then the agreement he made only mempuyai strength of evidence as a agreement under hand or aktanya degraded. ${ }^{15}$

As a result of the implementation of these provisions is not actually very detrimental to the parties, especially those who provide loans (creditors) of the borrower (debtor). Because if the agreement be degraded or agreement under difficult circumstances hand the creditor when once the event of default and needs to be in foreclosure.

Article 1866 of the Civil Code states that the evidentiary tool includes the written evidence,

\footnotetext{
${ }^{10}$ Results Interview with Maya as the Unit of Bank Supervisor dated June 82018 Primary data is processed

${ }^{11}$ Ibid.

12 Ibid.

${ }^{13}$ Results Interview with Lia as the bank branch office staff dated June 82018 Primary data.

${ }^{14}$ Ibid.

${ }^{15}$ Ibid.
} 
witness evidence, conjecture, acknowledgment, oath. Everything is subject to the rules set forth in the following chapters. Clear that the first written evidence placed of all the evidence mentioned in the article. The most important function is the agreement as evidence. $^{16}$

In terms of proving the agreement has several functions, $\mathrm{ie}^{17}$ Agreement serves as a formality authorization A certificate serves as a condition to declare the existence of a legal act, agreement serves as evidence The main function of the agreement is as evidence, the certificate serves as probationis power In this case the agreement to be the only evidence that can and legitimately prove a thing or event.

Based on interviews with Edy Suparno responsibility towards their Notary agreement only has the strength of evidence as the agreement under the hand when the agreement null and void and cause harm to the parties, in which case the Notary should be accountable to civil and Offenses. ${ }^{18}$

Civilly can be requested compensation, fees and interest due to the civil case the agreement made. In criminal court decision based on a agreement of Notary concerned, the certificates that have been made against the cancellation. ${ }^{19}$

If the agreement in for him otherwise has the strength of evidence as the agreement under hand by the District Court and proved that Notary concerned legally violate the rules of criminal then the agreement can be canceled and the Notary can be given administrative sanctions in the qualification as a public official even to sentenced jail. ${ }^{20}$

The administrative sanctions is governed by Article 7, Article 16, number 11 and 13, Article 17, Article 19, Article 32, Article 37, Article 54 and Article 65 A UUJN-P, based on the articles of the type of administrative sanction is a verbal warning, written warning, suspension, dismissal with respect, and a dishonorable discharge.

Factors that become obstacles in implementing the provisions of Article 16 paragraph (1) line $M$ the first are the large number of jobs of notaries who cause Notary unable to attend any such work that is necessary to represent / mengkuasakan to staff / employees to appear before signing parties to the agreement.

Too much of this work usually occurs on the banks of units is often a job (loans to borrowers) with a small nominal but are required to achieve the target which is quite large, so it needs to look for many debtors to be shut out of the specified target.

Both are minimal credit limit that causes the less Notary fee so most Notary prefer jobs that generate income is greater than the nominal attending a job with a small can in empowered / delegated to staff / employees.

Third less understanding of the parties to the provisions of Article 16 paragraph (1) line $M$ UUJN so that this provision can not be implemented in the Notary office activity and sometimes even no pulu from notaries who do not know and understand their obligations towards the implementation of these provisions.

Based on factors such constraints authors conducted interviews with Aminuddin As the Honorary Board of the Regional and Notary PPAT in Pekalongan, he said a solution to the constraints mentioned above, namely the first Notaries need to measure ourselves in the sense of need to know how many Notaries can hold jobs that can be done in his activity

\footnotetext{
${ }^{16}$ Sudikno Mertokusumo 2006 Hukum Acara Perdata Indonesia Liberty Yogyakarta (hereinafter written Sudikno Mertokusumo II) p.162

${ }^{17}$ M. Yahya Harahap 2009 Hukum Acara Perdata, Sinar Grafika Jakarta p.564

${ }^{18}$ Results Interview with Edy Suparno-PPAT as a Notary Public in Pekalongan dated June 292018 primary data processed

${ }^{19}$ Ibid.

${ }^{20}$ Ibid.
} 
that does not deviate from UUJN and Notary Code. ${ }^{21}$

Both do not discriminate against any occupation, Notary professionals must serve every job either work with a small income or a job with a large income. The job requires the same service that the parties feel all the services provided by the Notary. ${ }^{22}$

Even based on Article 37 UUJN-P are determined Notary is obliged to provide legal services in the field of notaries free of charge to those who can not afford. Notaries who violate these provisions will be subject to sanctions in the form of a verbal warning to dismissal with no respect.

Third periodic training given to the Notary by the supervisor or supervisors Notary regarding the understanding and knowledge about notaries who support the activities of his office. It is necessary in addition to tighten the relationship of the Notary also can make it a forum to exchange ideas on the problems faced by the Notary in running position thus minimizing the occurrence of violations by Notary. ${ }^{23}$

\section{Closing}

\subsection{Conclusion}

Based on the results of research and discussion that has been expressed by the author, it can be concluded as follows:

- Public notary in Pekalongan in carrying out his activities as a public official has not implemented the provisions of Article 16 (1) UUJN especially in jobs that carry little risk of default. Problems like this can be easily found on the creditor / bank office unit that has a nominal credit limit with quite small. Notary so often empowering / depute staff / employees to attend the signing of the agreement in front of the party.

- legal effects violation of the provisions of Article 16 paragraph (1) of this UUJN that agreement in question only has the strength of evidence as the agreement of the agreement under hand or degraded even until the agreement could be declared null and void by a court decision. Notary liable for such infringement can be held in both civil and criminal. Civilly can be requested compensation, fees and interest due to the civil case the agreement made. In criminal court decision based on a agreement of Notary concerned, the certificates that have been made against the cancellation.

- Obstacles encountered in the implementation of these provisions are too large number of jobs of Public Notary, too small a value leads to low credit limit so that the Notary fees, and less understanding of the parties and the Notary of the provisions of Article 16 paragraph (1) line M UUJN.

\subsection{Suggestion}

- Notary to still adhere to the rules Notary and Notary Code so as to avoid violations that led to the loss of the parties and the notary itself.

- For supervisors and coaches Notaries need to provide training and a forum to exchange ideas on the problems in the world regularly notaries.

- For the people are expected to understand and know the rules Notary so that it can participate in minimizing the occurrence of violations of the provisions of the Notary.

\footnotetext{
${ }^{21}$ Interview with Aminuddin as the Honorary Board of the Regional and Notary PPAT in Pekalongan dated June 292018 primary data

${ }^{22}$ Ibid.

${ }^{23}$ Ibid.
} 


\section{References}

[1] Daeng Naja 2012 Teknik Pembuatan Akta (Buku Wajib Kenotariatan) First Edition Buku Seru Jakarta.

[2] Habib Adjie 2015 Penafsiran Tematik Hukum Notaris Indonesia Berdasarkan undang Undang Nomor 2 Tahun 2014 Tentang Perubahan Atas Undang Undang Nomor 30 Tahun 2004 Tentang Jabatan Notaris Refika Aditama Bandung.

[3] Interview with Aminuddin as the Honorary Board of the Regional and Notary PPAT in Pekalongan dated June 292018 primary data

[4] M. Yahya Harahap 2009 Hukum Acara Perdata, Sinar Grafika Jakarta.

[5] Results Interview with Edy Suparno-PPAT as a Notary Public in Pekalongan dated June 292018 primary data processed

[6] Results Interview with Lia as the bank branch office staff dated June 82018 Primary data.

[7] Results Interview with Maya as the Unit of Bank Supervisor dated June 82018 Primary data is processed

[8] Sudikno Mertokusumo 2006 Hukum Acara Perdata Indonesia Liberty Yogyakarta (hereinafter written Sudikno Mertokusumo II).

[9] Suhrawardi K. Lubis 2006 Etika Profesi Hukum Sinar Grafika Jakarta.

[10] Tan Thong Kie 2000 Serba-serbi Praktek Notaris Book I PT Ichtiar New Van Hoeve Jakarta.

[11] Code of Civil law

[12] Act No. 2 of 2014 On Notary 